ISSN 2564-3843

DOI 26443/glsars.v1i1.133

\title{
EQUAL RIGHTS AND OPPORTUNITIES, DURING THE COVID-19 PANDEMIC, IN CONSIDERATION OF THE HUge DifFERENCE BETWEen Big CITIES AND SMALl TOWNS*
}

\begin{abstract}
The current pandemic has imposed the need to apply protective measures to prevent the spread of the virus. These include, in particular, restrictions on freedom of movement, with all the ensuing consequences. In some states, governments have chosen to impose total lockdowns for a certain period, which is useful for lowering the levels of contagion, while others have preferred to adopt semi-lockdowns. The Italian government, for example, in recent months, has chosen to divide the regions into colors: red, orange, yellow, green and white, depending on the needs and severity of the conditions within each territory. The decisions that have been made, however, do not take into account the important differences between regions, given that some of them offer more opportunities than others, nor they have considered the differences between cities and towns. In fact, there is a huge difference between people who live in big cities with all the conveniences that allow them to live comfortably for some time within their own municipalities, and people who live in small towns, where there are no opportunities for recreation or where, more generally, the same opportunities do not exist. Therefore, stopping people, for many consecutive days, from moving between one municipality and another, as happens for those who live in red and orange regions, means violating the principle of equality and other fundamental rights related to the expression of personality. In situations of extreme emergency, such as the current one, therefore, it is important to consider the idea of revising cities and towns, adapting services to actual needs, in order to balance the protection of public health with the right of the citizens to live in dignity. The government restrictions of fundamental rights should never be discriminatory, but always proportionate, according to the context in which they are applied. When it becomes difficult for mothers to even reach hospitals to give birth to their babies, or for people to access essential services due to restrictions, it becomes necessary to ask how the space of the actual cities should be reviewed during the COVID-19 pandemic.
\end{abstract}

\footnotetext{
Mariangela Barletta; $\mathrm{PhD}$ candidate at "La Sapienza" University. Contact: 
Keywords: Covid-19, Human rights, Confinement measures, Law and the city, equality

\section{Résumé}

La pandémie actuelle a mené à l'imposition de mesures de protection pour empêcher la propagation du virus. Celles-ci comprennent notamment des restrictions à la liberté de mouvement, avec toutes les conséquences qui en découlent. Dans certains États, les gouvernements ont choisi d'imposer un confinement total pendant une certaine période (ce qui est utile pour abaisser les niveaux de contagion). D’autres ont préféré adopter un confinement moins restrictif. Le gouvernement italien, par exemple, a, au cours des derniers mois, divisé les régions en couleurs (rouge, orange, jaune, vert et blanc) en fonction des besoins et de la gravité des conditions sanitaires. Les décisions qui ont été prises ne tiennent toutefois pas compte des différences importantes entre les régions ni des différences entre les villes et les villages. En effet, il existe une énorme différence entre les personnes qui vivent dans de grandes villes et les personnes qui vivent dans de petites villes où il n'y a pas de possibilités de loisirs ou, plus généralement, les possibilités sont moins diverses.

Par conséquent, empêcher les personnes de certaines régions de se déplacer d'une commune à l'autre pendant plusieurs jours consécutifs (comme c'est le cas pour celles qui vivent dans les régions rouge et orange) contrevient non seulement au principe d'égalité, mais également à d'autres droits fondamentaux liés à l'expression de la personnalité. Dans des situations d'extrême urgence, comme celle que nous vivons actuellement, il est important d'étudier l'impact des restrictions au sein des villes et des villages. Ceci permet d'adapter les services aux besoins réels ainsi que d'équilibrer la protection de la santé publique et le droit des citoyens à vivre dans la dignité. Les restrictions des droits fondamentaux ne doivent jamais être discriminatoires. Elles doivent également être proportionnées en fonction du contexte dans lequel elles sont appliquées. Lorsqu'il devient difficile pour les mères d'atteindre les hôpitaux afin de donner naissance ou pour les citoyens d'accéder aux services essentiels en raison de restrictions imposées par le gouvernement, il devient nécessaire de se demander comment l'espace des villes devrait être revu pendant la pandémie de COVID-19. 
Mots-clés : Covid-19, droits de la personne, mesures de confinement, droit et ville, égalité

\section{INTRODUCTION}

Covid-19 has revealed problems that are not only health-related, but also have socioeconomic implications. Worldwide, since the outbreak of the pandemic, gaps between nations and within nations have increased. In fact, many states have shown their inabilities to guarantee the same level of opportunities among their territories, especially between large cities and small towns. These gaps, which were already present, have been exacerbated by the imposition of restrictive measures adopted by national governments to contain the spread of the virus, which have confined people in their cities or have imposed the closure of the main commercial activities. These limitations, although intended to find a balance between individual and collective rights to health, have forced many people's wellbeing in risk, especially those living in small towns and rural areas, where they are generally more disadvantaged.

Therefore, considering the importance of the function of the city in people's life, the aim of this paper is to investigate the relationship between law and city during and after the Covid-19 pandemic, with a focus on the major disparities between small towns and large urban centers. These inequalities among different areas must be discussed, trying to find solutions that ensure that everyone may have equal rights and opportunities, both to access to essential services and to employment.

To this end, in the first section, the article will highlight the current socio-economic issues that have arisen in cities as a result of the pandemic, focusing on the issue of employment - especially for women - to the access to relevant facilities, and, more broadly, to the topic of maintaining an adequate standard of living and mental well-being throughout the population. The analysis of this situation, within the nations, will lead to assess whether there are human rights violations, although 
the imposition of government restrictive measures is generally legitimated under international law. On the basis of these considerations, the recommendations that the United Nations have proposed to protect the rights of people living in cities during the pandemic will be examined. In addition, the value of the principle of leave no one behind ${ }^{1}$, which has been acknowledged in the purposes of the Sustainable Development Goals (SDGs) of the Agenda 2030 and the New Urban Agenda (NUA) will be explained. In accordance with these guidelines, how Member States have implemented the proposed international models will be discussed, with the case of Italy as an example, which has been especially hit by the pandemic and where the gap among cities is expected to expand further. Finally, it will attempt to demonstrate that one reasonable solution to the problem of inequality among cities within the same national territory may be to create more compact cities. For instance, through the extension of the actual urban boundaries of smaller cities until they reach the same population density as larger ones. Despite its drastic nature, Covid-19 can provide an incentive to build compact and inclusive places in order to develop new forms of living cities. Indeed, if municipalities continue to be segregated along these parameters, it would become increasingly difficult to leave no one behind.

\section{PART 1. THE SOCIOECONOMIC PROBLEMS OF THE PANDEMIC}

The socioeconomic implications of the pandemic have attracted different parties' attention, due to the gap that Covid-19 has widened not only among states, but also among cities within the same

\footnotetext{
${ }^{1}$ Leave no one behind (LNOB) is the central, transformative promise of the 2030 Agenda for Sustainable Development and its Sustainable Development Goals (SDGs). It represents the unequivocal commitment of all UN Member States to eradicate poverty in all its forms, end discrimination and exclusion, and reduce the inequalities and vulnerabilities that leave people behind and undermine the potential of individuals and of humanity as a whole. See. UNSDG, 'Universal Values, Principles' < https://unsdg.un.org/2030agenda/universal-values/leave-no-one-behind> accessed 18 June 2021
} 
territory. The pandemic, in fact, has worsened already established economic and social disparities, bringing almost 100 million individuals below the poverty line in $2020 .^{2}$ This situation has become more complicated also because of the national governments' restrictive measures adopted to contain the spread of the virus, that have not always taken into account the huge inequalities among cities on their own territory, especially those between small and large cities. ${ }^{3}$ In fact, in smaller towns, the imposition of confinement measures makes it more difficult to access the same opportunities both for essential services - such as first aid and reproductive services - as well as employment - especially for women.

Employment has declined sharply due to the closing of main business activities as well as the struggle in finding new employment. In smaller and decentralized areas seeking for jobs have become extremely difficult, because confinement measures often do not allow to leave the area of residence. In addition, sometimes, people who live in small or rural towns are not able to work from home daily. In fact, in many areas there is frequently a lack of signal, or, more broadly, a lack of free hotspots. This digital gap is also caused by the difficulty of using a good quality connection simultaneously in a family, in view of the fact that internet devices may be used by all family members. For women who live far from a large city, the employment problem is much bigger. ${ }^{4}$ In

2 UN-HABITAT, 'Global Compendium of Practices on Local Economic and Financial Recovery' (2021) 8.

3 Ayyoob Sharifi and Amir Reza Khavarian-Garmsir, 'The COVID-19 pandemic: Impacts on cities and major lessons for urban planning, design, and management' (2020) 749 (142391) Science of The Total Environment <https://doi.org/10.1016/j.scitotenv.2020.142391>; Michele Acuto and Shaun Larcom, 'Seeing COVID-19 through an urban lens' (2020) 3(3) Nature Sustainability 977-978. <https://doi.org/10.1038/s41893-02000620-3>

4 Eruchalu, C.N., Pichardo M.S., and others 'The Expanding Digital Divide: Digital Health Access Inequities during the COVID-19 Pandemic in New York City' (2021) 98, J. Urban Health 183-186 $<$ https://doi.org/10.1007/s11524-020-00508-9>; Anita Ramsetty, Cristin Adams, 'Impact of the digital divide in the age of COVID-19', (2020) 27(7) <https://doi.org/10.1093/jamia/ocaa078>; EU PARLAMENT, 'The coronavirus crisis: An emerging gender divide?' 
fact, it is often assumed, even due to cultural currents, that they should remain at home to care for children attending school remotely from home. In this sense, the economic impacts of Covid-19, in terms of opportunity to find a job, have also sharpened along gender lines. ${ }^{5}$

National governments' restrictive measures have also made it more difficult for people to have equal access to essential services. The health system, in particular, has been seriously affected in some areas as a result of the conversion of some local hospitals into Covid-19 hospitals. This has made access to first aid difficult because people are forced to move to another location to access it. Furthermore, the problem of limited access to medical care is particularly dangerous in relation to both childbirth and abortion. The latter, due to the lack of a cohesive solution to sustaining abortion care, as well as limits and border closures, has intensified inequalities. In this respect, the WHO has called for the use of telemedicine to administer medication-assisted abortions from home. However, only a few Member States of the WHO have considered this proposal until now. ${ }^{6}$

The disparities between those living in big cities and those living in small towns also concerns the general standard of living and mental health. In fact, in many isolated areas, except in the case

\footnotetext{
<https://www.europarl.europa.eu/RegData/etudes/ATAG/2021/679100/EPRS ATA(2021)679100_EN.pdf $>$ accessed 18 June 2021; see infra

5 Women are another category of people more likely to be negatively impacted by pandemic. According to McKinsey's report women's jobs in 2020 are 1.8 times more vulnerable to this crisis than men's jobs. Women make up 39 percent of global employment but account for 54 percent of overall job losses. Anu Madgavkar and others, (2020) Mckinsey website < https://www.mckinsey.com/> accessed 2 May 2021
}

6 WHO, 'Maintaining essential health services: operational guidance for the COVID-19 context' (2020) $<$ https://apps.who.int/iris/bitstream/handle/10665/332240/WHO-2019-nCoV-essential health services2020.2-eng.pdf $>$ accessed 3 May 2021; Julia Hussein, 'COVID-19: What implications for sexual and reproductive health and rights globally?' (2020) 28(1) Sexual and Reproductive Health Matters <https://doi.org/10.1080/26410397.2020.1746065> accessed 2 May 2020; Jessica MacKinnon, Alexane Bremshey, 'Perspectives from a webinar: COVID-19 and sexual and reproductive health and rights', (2020) 28(1) Sexual and Reproductive Health Matters < https://doi.org/10.1080/26410397.2020.1763578 > accessed 2 May 2020 
where no one is allowed to leave the house, it is not possible for everyone to access to well-equipped sports facilities for open-air activities. In the same way it is not possible to meet friends or relatives who live outside the city in quarantine, even taking precautions. In this situation, the assessment of mental well-being has been negatively affected as a consequence of isolation and loss of work. In a E.U. survey, several participants have been found to suffer from Covid-19's anxiety, depression, and uncertainty about their future. 7

In order to fill the gaps among cities, it is needed to address the inadequate state of public services in many areas, which has been exacerbated by years of disinvestment and poorly managed privatization of public services in many cases. ${ }^{8}$ In this sense, the measures taken by governments during the pandemic must not be a greater obstacle to equality. Situations in which there is a risk of leaving part of the population too far behind need to be examined according the main international instruments for the protection of human rights.

\section{PART 2. HUMAN RIGHTS IN STATES OF EMERGENCY IN INTERNATIONAL LAW}

Governments' restrictive measures during the Covid-19 pandemic have limited certain human rights. In general, states are permitted, under international law, to take measures that limit or restrict the enjoyment of individual rights and freedoms in emergency situations, such as conflicts or other

\footnotetext{
7Samantha K Brooks and others, 'The psychological impact of quarantine and how to reduce it: rapid review of the evidence' (2020) 395(10227) The Lancet <https://doi.org/10.1016/S0140-6736(20)30460-8 > accessed 2 May 2021; Vincenzo Giallonardo and others, 'The Impact of Quarantine and Physical Distancing Following COVID-19 on Mental Health: Study Protocol of a Multicentric Italian Population Trial' (2020) 11 Frontiers in Psychiatry <https://doi.org/10.3389/fpsyt.2020.00533 > accessed 2 May 2021; James G Rubin, Simon Wessely, 'The psychological effects of quarantining a city' BMJ (2020) <https://doi.org/10.1136/bmj.m313> accessed 2 May 2021. For the EU survey visit <https://ec.europa.eu/eusurvey/runner/COVIDSurvey2020 $>$ 8 UN, 'Policy Brief: COVID-19 in an Urban World' (2020) <https://unsdg.un.org/sites/default/files/202007/sg_policy brief_Covid urban world.pdf $>$ accessed 3 May 2021
} 
major social upheavals. ${ }^{9}$ However, these measures may be applied under strict conditions according to the International Covenant on Civil and Political Rights (art. 4), the American Convention on Human Rights (art. 27), and the European Convention on Human Rights (art. 15 CEDU) provisions. ${ }^{10}$ Some rights, which are defined with the term "jus cogens", cannot be limited and must always be respected by all.11 This consideration does not imply that all rights not included in this

9 Laura Pineschi, Il patto delle Nazioni Unite sui diritti civili e politici. in Laura Pineschi (ed), La tutela internazionale dei diritti umani (Giuffrè 2006) 78-112; Claudio Zanghì, La protezione internazionale dei diritti dell'uomo, (Giappichelli 2019); OHCR, Human Rights in the Administration of Justice: A Manual on Human Rights for Judges, Prosecutors and Lawyers (United Nations 2003) 813

${ }^{10}$ Contrary to the International Covenant on Economic, Social and Cultural Rights, which contains only a general provision inspired by article 29 of the Universal Declaration of Human Rights, the European Social Charter envisages the possibility of derogation both in its original version (art. 30) and in its revised version (Part V, art. F); Article 4(1) of the International Covenant on Civil and Political Rights provides that: "In time of public emergency which threatens the life of the nation and the existence of which is officially proclaimed, the States Parties to the present Covenant may take measures derogating from their obligations under the present Covenant to the extent strictly required by the exigencies of the situation, provided that such measures are not inconsistent with their other obligations under international law and do not involve discrimination solely on the ground of race, color, sex, language, religion or social origin." ; Article 27(1) of the American Convention on Human Rights reads as follows: "In time of war, public danger, or other emergency that threatens the independence or security of a State Party, it may take measures derogating from its obligations under the present Convention to the extent and for the period of time strictly required by the exigencies of the situation, provided that such measures are not inconsistent with its other obligations under international law and do not involve discrimination on the ground of race, color, sex, language, religion, or social origin." Article 15(1) of the European Convention on Human Rights stipulates that: "In time of war or other public emergency threatening the life of the nation any High Contracting Party may take measures derogating from its obligations under this Convention to the extent strictly required by the exigencies of the situation, provided that such measures are not inconsistent with its other obligations under international law."

${ }_{11}$ The right to freedom from torture, cruel, inhuman and degrading treatment or punishment, and medical or scientific experimentation without one's free consent - article 7; The right to freedom from slavery, the slave trade and servitude - article 8; The right not to be imprisoned on the ground of inability to fulfil a contractual obligation - article 11; The right not to be subjected to retroactive legislation (ex post facto laws) - article 15; The right to recognition as a person before the law - article 16; The right to freedom of thought, conscience and religion - article 18; The right not to be subjected to the death penalty - article 6 of the Second Optional Protocol 
definition can be derogated unconditionally, even during an emergency. ${ }^{12}$ Derogatory measures must, in fact, be "strictly required by the exigencies of the situation," proportionate, and take into account the territorial, temporal, and material range of the emergency. ${ }^{13}$ Furthermore, they must not be incompatible with a State party's other relevant international obligations, and they must not involve discrimination solely on the basis of race, color, sex, gender, religion, or social background. ${ }^{14}$ Therefore, in order to avoid discriminations when applying rights' limitations, governments must take into account the specific territorial needs in which the measures will be applied, while ensuring that these will remain in force only for the period of time strictly necessary to overcome the emergency. The prohibition of unjustified discrimination is also expressed by Syracuse principles, which recall how, in the proclamation of a public emergency, both "bona fides" and an objective evaluation of the situation must be considered. ${ }^{15}$

In the case of Covid-19, it appears that governments did not take into account the significant differences among cities within the same State, adopting measures that worsened inequities, despite the fact that those actions were legal. Therefore, in this scenario, it is important to appeal to the right to equality, which includes access to essential facilities, employment opportunities, and internet

\footnotetext{
${ }^{12}$ In this sense is the point. n. 6 of the International Covenant on Civil and Political Rights, General Comment n. 29 on article 4 of the Covenant, 31 August 2001

${ }^{13}$ Ireland v UK (1978) 252 79; OHCR, 'Human Rights in the Administration of Justice', 859.

${ }_{14}$ According to Article 4 (1) of the International Covenant on Civil and Political Rights, Article 27 (1) of the American Convention on Human Rights, and Article 15 (1) of the European Convention on Human Rights law ${ }_{15}$ American Association for the International Commission of Jurists, Syracuse principles on the Limitation and Derogation Provisions in the International Covenant on Civil and Political Rights, 1985. The Syracuse Principles also require that an adjustment to the rights or freedoms enshrined in the Covenant: (a) be based on one of the reasons justifying the documentation recognized by the relevant article of the Covenant; (b) respond to a pressing public or social need; (c) pursue a legitimate purpose; (d) be proportionate to this objective; and (e) be resolved in the shortest time necessary to put an end to the public emergency that threatens the life of the nation
} 
services, as well as to the right to an acceptable standard of living, which includes the right to social dignity and general well-being. These values are safeguarded on both national and international level. ${ }^{16}$

The right to equality and non-discrimination is a cornerstone of universal human rights law. It is recognized in art. 2 UDHR (Universal Declaration on Human Rights) ${ }^{17}$ and it is included in other UN human rights instruments, such as arts. 2 and 26 ICCPR (International Covenant on Civil and Political Rights) ${ }^{18}$, art. 2 par. 2 ICESCR (International Covenant on Economic, Social, and Cultural Rights) ${ }^{19}$, art. 2 CRC (Right of the Child) ${ }^{20}$, and art. 5 CRPD (Convention on people with disability) ${ }^{21}$. The principle is also enshrined in regional documents, such as art. 2 of the American Declaration ${ }^{22}$, art. 24 of the American Convention on Human Rights ${ }^{23}$, arts. 2 and 3 of the African Charter on Human and People's Rights ${ }^{24}$, and art. 4 of the European Social Charter. ${ }^{2526}$

\footnotetext{
${ }^{16}$ Lauro Zagato, 'L'eccezione per motivi di emergenza nel diritto internazionale dei diritti umani' (2006) 5(6) DEP 137-156; Laura Pineschi, 'La tutela internazionale', cit., 78-112

${ }_{17}$ Art. 2 UDHR (Universal Declaration on Human Rights), 1948

${ }_{18}$ Art. 2 and art. 26 ICCPR (International Covenant on Civil and Political Rights), 1966. Therefore, legislative measures setting out unreasonable distinctions between individuals regarding the economic, social and cultural rights, set forth in the Covenant, constitute a violation of the article 26 ICCPR

19 Art. 2 par. 2 ICESCR (International Covenant on Economic, Social, and Cultural Rights), 1966

${ }^{20}$ Art. 2 CRC (Right of the Child), 1989

${ }^{21}$ Art. 5 CRPD (Convention on people with disability), 2006

22 Art. 2 of the ADHR (American Declaration of Human Rights), 1948

${ }^{23}$ Art. 24 of the ACHR (American Convention on Human Rights), 1969

24 Arts. 2 and 3 of the ACHPR (African Charter on Human and People's Rights), 1981

25 Art. 4 of the ESC (European Social Charter),1961

${ }^{26}$ In addition, different European Union Council Directives address discrimination, inter alia, 2000/78/EC which sets out measures for equal treatment in employment
} 
The same level of legal protection is deserved to the right to an adequate standard of living, in order to support people to meet their basic needs in dignity ${ }^{27}$. This right requires that everyone has the appropriate subsistence rights, free of excessive obstacles, in order to participate fully in normal, daily interactions with other people. It includes the right to sanitation, the right to work, the right to physical and mental health, and the general well-being. ${ }^{28}$ It is provided by several instruments on human rights protection. For instance, in art. 25 para. 1 of the UDHR ${ }^{29}$, which identifies its elements, art. 11 of the ICESCR ${ }^{30}$, art. 27 of the CRC ${ }^{31}$ and, at the regional level, the art. $26 \mathrm{ACHR}^{32}$, which encourages governments to take measures to guarantee 'the full realization of the rights implicit in the economic, social, educational, scientific, and cultural standards set forth in the Charter'. Furthermore, the protection of this right is also ensuring by the Declaration on the Right to Development (art. 8) 33as well as the Habitat Agenda (e.g. paragraphs 13, 31 and 105) ${ }^{34}$.

\footnotetext{
${ }^{27}$ The term "adequate" is explained by ICESCR General Comment 12 finds that what is 'adequate' 'is to a large extent determined by prevailing social, economic, cultural, climatic, ecological and other conditions'

28 WHO, UNICEF, 'Water, Sanitation, Hygiene, and Waste Management for the COVID-19 Virus' (2020) < https://apps.who.int/iris/rest/bitstreams/1272446/retrieve> accessed 1 May 2021

${ }^{29}$ Art. 25 para. 1 of the UDHR 'Everyone has the right to a standard of living adequate for the health and wellbeing of himself and his family'

3o Art. 11 of the ICESCR

${ }^{31}$ Art. 27 of the CRC

32 Art. 26 ACHR

33 Art. 8 Declaration on the Right to Development,

34 Arts. 13, 31, 105 Habitat Agenda III, 2016. The Habitat Agenda deserves particular attention to high standard of living. For instance, it, takes into considerations some of the SDG'S goals, such as n. 1, 5, 8 and 11:

1) End poverty in all its forms everywhere; 5) Gender equality; 3) Decent work and economic growth; 11) Sustainable cities and communities
} 
For example, in accordance with Habitat Agenda III, authorities have to promote settlement development policies which ensure equitable maintenance and access to basic services, such as education, employment, well-being, and open space areas. 35

During the Covid-19 pandemic, the human rights protection has been a particular concern of UN organizations, such as the World Health Organization (WHO) and UN-Habitat. These Agencies have highlighted the important role of cities in contrasting the spread of the virus while ensuring the respect of the citizens' rights. In this sense, they have worked, often through partnerships, to find a solution to protect human rights during the pandemic, especially in situations of massive disparities and disadvantages, reflecting on the city's function and on the possible solution to ensure to all the equality to the ongoing and prospective scenarios.

Part 3. The Role of THE United Nations in the Cities AND URban SETTLEMENTS FOR OPTIMAL PREPAREDNESS

With the outbreak of the pandemic, the United Nations has issued documents and recommendations to facilitate authorities and policymakers in the governance of cities and other urban settlements, both during and after the emergency. ${ }^{36}$ These documents identify appropriate measures that might enhance city management during Covid-19, while also taking into account the disadvantages of certain state areas and the human rights protection. Although these documents are not legally binding, they contain valuable guidelines that states must observe. In this regard, they play an important role both in bringing the current pandemic to an end, but also in contributing to the achievement of the principle of "leaving no one behind", expressed in the Sustainable Development

35 UN-HABITAT, 'The Habitat Agenda Goals and Principles, Commitments and the Global Plan of Action' (1996) para 116, 48

${ }^{36}$ Infra 
Goals (SDGs) of the Agenda $2030^{37}$, and in the New Urban Agenda (NUA) ${ }^{38}$, which ensure the sustainable and inclusive economies and the environmental sustainability.

First of all, the United Nations established a framework for the immediate socioeconomic response to Covid-19 in April 2020, emphasizing the need to "empower local governments; scale neighborhood and city level resilience." 39 The recovering better principles of the UN framework were also considered by the UN Secretary-General in the "Policy Brief on COVID-19 in an Urban World". ${ }^{40}$ In the report, it has been recommended to understand diversity and to strengthen local governments, in order to avoid the interruption of essential services and to sustaining gender equality and local workers through the development of specific strategies of that area according to the situation. ${ }^{41}$

The UN has also launched a project known as "Building Urban Economic Resilience during and after COVID-19" to help local and small towns become more inclusive and resilient to the pandemic. $4^{2}$ It was established by United Nations regional agencies in partnership with the United

37 UN, 'Transforming our world: the 2030 agenda for sustainable development', (2015) A/RES/701. Goal 11: Make cities inclusive, safe, resilient and sustainable. See $<$ https://www.un.org/sustainabledevelopment/cities/> accessed 3 May 2020

${ }^{8}$ UN, 'New Urban Agenda' (2016) <https://uploads.habitat3.org/hb3/NUA-English.pdf> accessed 3 May 2021

39 See UN, 'A UN framework for the immediate socio-economic response to COVID-19' (2020) $<$ https://unsdg.un.org/sites/default/files/2020-04/UN-framework-for-the-immediate-socio-economicresponse-to-COVID-19.pdf $>$ accessed 3 May 2021

40 UN, 'Policy Brief: COVID-19 in an Urban World'

${ }^{41}$ Ibidem, 4

${ }^{42}$ This is a program which develops guidelines for cities that choose to join the network, which can be implemented for cities to increase their ability to build long-term urban resilience. The network provides training courses and workshops with government staff and partners from the cities participating in the initiative. The program is available at <https://urbanresiliencehub.org/economicresilience/ $>$ accessed 25 April 2021 
Nations-Habitat City Resilience Global Program (CRGP) 43 and the United Nations Capital Development Fund (UNDF)44, with the aim of strengthening the capacities of local governments, which probably are better able to manage stresses such as Covid-19 in their territories. Its goals also include developing strategies for planning and constructing resilient cities, promoting a green and circular economy, overcoming inequality, and assisting the most disadvantaged groups, while paying especially attention to the principle of "leaving no one behind". 45 The principle, which, as we have already seen, constitutes one of the major aspect of the UN's 2030 Agenda, requires the analysis of human rights and gender impacts to inform the design of policies, as well as the development of strategies to employ disadvantaged groups.

Recently, UN-Habitat has reported in a Compendium how participant cities of this UN Project reacted to the pandemic while adopting measured according to the issued guidelines ${ }^{46}$. The

43UN-HABITAT, 'City resilience profiling tool' (2018) < http://urbanresiliencehub.org/wpcontent/uploads/2018/02/CRPT-Guide.pdf > accessed 20 April 2021

44 This project is a joint partnership between UN Economic Commission for Europe (UNECE), UN Economic Commission for Africa (UNECA), UN Economic and Social Commission for Western Asia (UNESCWA), UN Economic Commission for Latin America and the Caribbean (UNECLAC), UN Economic and Social Commission for Asia and the Pacific (UNESCAP), United Nations Capital Development Fund (UNCDF) and UN-HABITAT City Resilience Global Program (CRGP)

45 The term "resilient city" is based on the five principles expressed in the document "City resilience profiling tool" issued by the UN-HABITAT, which reflect the call for local authorities to actively engage in building a people-centric and holistic approach, especially as the COVID-19 crisis has highlighted the interconnectedness of urban systems. Furthermore, since the project focuses also on the impact of the Covid-19 urban economy, UNCDF has created a "Conceptual Framework for Urban Economic Resilience", which defines urban economic resilience as "the development of inclusion and the management of the economic impact of the pandemic. For more information visit UN-HABITAT, Urban Resilience HUB, (online) <www.urbanresiliencehub.org> accessed 3 May 2021

46 UN-HABITAT 'Global compendium', 9 
aim of the analysis was to provide to cities across the globe an opportunity for peer-learning in developing and implementing their immediate response and recovery plans. 47

The WHO has been another UN agency which has paid particular attention to the relation between law and the city during Covid-19 pandemic. On this purpose, it has launched a "Partnership for Healthy Cities" 48 , to help contain the spread of the virus while ensuring that health and human rights were respected. The initiative aims to assist governments in responding to the emergency in an inclusive manner, by strengthening health infrastructure and essential resources. For this purpose, the WHO has even released a hub, in which it publishes a set of documents, such as "Strengthening preparedness for Covid-19 in cities and urban settings," or "Practical actions in cities" that include guidance and tools to help local governments to develop proper strategies in their territories 49 .

The importance deserved to rights by all of these policy instruments demonstrates how essential it is for all parties to cooperate in order to achieve the principle of "leaving no one behind". Unfortunately, while some states adopted these UN international guidelines to improve the standard

47 The survey was been completed by 29 cities. For the result see UN-HABITAT, “Global compendium”, 23. The objectives of the project are: (1) Regional and global showcasing of the experiences, practices and innovation of the city (2) Learning and insights from regional and global experiences from other cities and local authorities (3) Engagement and peer-learning through dialogue with other local authorities in the region and globally (4) Technical support towards the preparation of an economic and financial recovery and rebuilding strategy/plan for the city (5) Knowledge and evidence-based information on economic and financial dimensions of COVID-19 in the city as a basis for policy and decision-making

${ }^{48}$ Vital strategies, (Partnership for Healthy Cities) <https://cities4health.org/> accessed 2 May 2021

49 WHO, 'COVID-19 resource hub for cities and local governments' <https://www.who.int/teams/riskcommunication/cities-and-local-governments $>$ accessed 2 May 2021; WHO, 'Strengthening Preparedness for COVID-19 in Cities and Urban Settings', (2020) <https://www.who.int/publications/i/item/strengtheningpreparedness-for-Covid-19-in-cities-and-urban-settings > accessed 3 May 2021; WHO, 'Operational considerations for case management of COVID-19 in health facility and community' (2020)

<https://apps.who.int/iris/bitstream/handle/10665/331492/WHO-2019-nCoV-HCF operations-2020.1eng.pdf $>$ accessed 3 May 2021 
of life for their inhabitants, others are still far from reaching a decent degree of equality among all cities within their territories. For example, in Italy, there are still significant disparities across the country, particularly between large cities and small towns in the Southern regions, which force many people to face serious economic and social challenges. This consideration leads to the conclusion that probably policymakers should recognize pre-existing vulnerabilities prior to adopting severe restrictive measures.

\section{PART 4. THROUGH THE ANALYSIS OF CITIES RESPONSES: THE ITALIAN CASE STUDY}

Italy is a country which has been strongly affected by the pandemic. Initially, emergency management in the Italian context was even taken as an example by other states, because the measures adopted by the government seemed to work in containing the spread of the virus. However, those measures did not properly take into account the huge differences existing among Italian cities and regions, so they have exacerbated the inequalities that were already present in the State. $5^{0}$ These inequalities, which have particularly hit small towns and regions in Southern Italy, are primarily related to financial disparities and equal access to jobs, especially for women. In addition, strong disparities often include access to basic public services - such as first aid - and the quality of life more broadly. In small cities or local areas, for example, it might be difficult to connect to the internet.

\footnotetext{
50 Valentina Meliciani, 'La crisi pandemica in Italia e gli effetti sul divario Nord-Sud' (2020) LuissOpen <https://open.luiss.it/2020/11/29/la-crisi-pandemica-in-italia-e-gli-effetti-sul-divario-nord-sud/> accessed 20 April 2021; Flavia Amabile, 'La scuola negata al Sud Italia Persi il doppio dei giorni rispetto ai bambini del Nord' (2021) 10(10) LaStampa <http://www.flcgil.it/rassegna-stampa/nazionale/la-scuola-negata-al-suditalia-persi-il-doppio-dei-giorni-rispetto-ai-bambini-del-nord.flc $>$ accessed 20 April 2021; Cinzia Caporale and Alberto Pirni, 'Pandemia e resilienza: Persona, comunità e modelli di sviluppo dopo la Covid-19'(CNR edizioni 2020)
} 
These considerations contribute to the conclusion that, in order to prevent breaches of certain human rights, Italy should probably be more concerned with the UN guidelines, especially those relating to local sustainable development goals.

Indeed, the government's anti-spread measures are based on a tiered system which divides Italian regions into red, orange, yellow, green and white ones based on local Covid-19 risk. ${ }^{5^{1}}$ The designation is based on ordinances provided by the Ministry of Health, which determines the color of the district based on the severity of the condition in those zones, after the advice issued by the Technical Scientific Committee (CTS) and the presidents of the regions. The CTS takes into account the ISS (National Institute of Health) indices ${ }^{2}$, which are largely focused on health service resilience, without taking into account the other particular needs of the cities within the regions.

Generally, people living in red or orange zones are the most compromised because they are not allowed to leave their cities or towns, unless for essential needs such as work, health, or other emergency situations. Those who live in the red zone are also unable to move within their own municipalities. For towns with max 5.00o inhabitants the movement limitations were expanded to a range of $30 \mathrm{~km}$. Seeking a job in these situations is particularly problematic, and it is even more difficult for people living in small towns or cities in Southern Italy, since most of the territorial activities that generate economic income - tourism, lodging, and restaurant business - are closed.53

\footnotetext{
${ }^{51}$ Red (high risk), orange (medium risk), yellow (almost safe) and green (safe), for which specific restrictive measures are envisaged. The latest ordinance is 'Decreto-legge 22 aprile 2021, n. 52', $<$ https://www.governo.it/it/coronavirus-normativa>

${ }^{2}$ CTS considers the 21 indicators stablished by the ISS 'Epidemic Risk Analysis of the Regions' (2020) $<$ https://www.iss.it/documents/5430402/o/21+Indicators\%2C+Epidemic+risk+analysis + of + the+Regions.p df/2a954532-foe4-02e2-dfe9-48b887a863f8 $>$ accessed 3 May 2020

53 Most industries are located in northern Italy. The resilience index of these areas is higher, and many workers have returned to work. See Gianfranco Viesti, 'Ecco perché il Sud pagherà di più gli effetti della crisi' (2020) IlMessaggero < <https://www.ilmessaggero.it/economia/news/coronavirus sud crisi ultime notizie5144901.html> accessed 15 April 2021
} 
Inequalities between large and small cities are also significant in the orange zone. In fact, even though certain activities may continue to operate, in urban centers there is certainly a higher chance of receiving more consumers from the same city. For example, a shop in a small city cannot attract customers from another nearby city, so it would inevitably be more inclined to fail. Women, who are more likely to stay at home and care for children who do not attend school, are disproportionately affected by employment problems. Italy has one of Europe's widest gender disparities54. In fact, according to the Italian National Institute of Statistics (ISTAT), data relative to 2019 shows that female employment has decreased since the pandemic (-249 thousand employed, $-2,5 \%)$. However, ISTAT data shows that Italian employment rate has generally and significantly decreased in 2020 (456 thousand, $-2,0$ percent), which a significant increase in the number of inactive citizens. Inactivity rates have particularly risen in Italy's Southern regions (+1,8 percent), especially for women. 55

Restrictive measures adopted by governments have also affected the health system, making it difficult to easily access all health services. In particular, many Italian hospitals in small urban areas were turned into Covid-19 hospitals, forcing people to travel far from their towns in order to access the available first aid. $5^{6}$ Furthermore, access to healthcare is especially problematic due to

54 EIGE (European institute for gender), 'Gender Equality Index 2020: Digitalisation and the future of work' (2020) <https://eige.europa.eu/publications/gender-equality-index-2020-digitalisation-and-future-work> accessed 20 April 2021

55 ISTAT, 'Occupati e disoccupati (Dati provvisori)' (2021) <https://www.istat.it/it/archivio/256254> accessed 3 May 2021; ISTAT 'Il mercato del lavoro' (2021) <https://www.istat.it/it/archivio/254990> accessed 3 May 2021

56 ANSA, 'Napoli: trasformazione ospedale per covid; protesta cittadini' (2020) $<$ https://www.ansa.it/campania/notizie/2020/11/14/napolitrasformazione-ospedale-per-covid-protestacittadini b9a6b6ce-8e19-4447-ad94-a4c50a1eb5c2.html> accessed 20 April 2021 
inadequate hospital services or insufficient staff to ensure that everyone receives a rapid medical help. 57

Many of the ordinances that have been applied by Government have bypassed regional authorities' decisions. In fact, the Ministry of Health have decided that pandemic management should have been centralized, with regions having only a few and urgent opportunities to change their decisions. This divide between central and regional government has been much debated, and it remains contentious, with many regional and provincial authorities wishing to have more decisionmaking power in the administration of their territories. ${ }^{8}$ Leaving aside the Italian state discussion, it is important to consider the measures taken by the Government in view of the cited UN recommendations. As previously stated, the UN organizations, especially the UN-Habitat, and the WHO, have placed a strong emphasis on the importance of local government management in the construction of resilient cities, to allow everyone to enjoy the same rights. In this regard, the central government should strengthen its capacity to respond to the special needs of their regions, even by increasing financial assistance. This consideration does not necessarily imply that all powers should be transferred to local governments, as in bottom-up policies, but it does imply that the State should facilitate the same opportunities to all, especially considering the gender gap, while recognizing the

\footnotetext{
57 Paolo G. Brera, Coronavirus, 'allarme Sud: "Ospedali poco attrezzati per l'emergenza"' La Repubblica (2020)<https://www.repubblica.it/cronaca/2020/03/06/news/coronavirus_allarme_sud-250378144/> accessed 25 April 2021

58 Marco Mandato, 'Il rapporto Stato-Regioni nella gestione del Covid-19' (2020) (1) Nomos 2; Annamaria Poggi, 'Tornare alla normalità dei rapporti Stato Regioni. Errori da evitare e lezioni da meditare' (2020) (25) Federalismi; Antonio Ruggeri 'Il coronavirus contagia anche le categorie costituzionali e ne mette a dura prova la capacità di tenuta' Rivista di diritto delle autonomie territoriali (2020); Antonio D’Aloja 'L'art. 120 Cost., la libertà di circolazione e l’insostenibile ipotesi delle ordinanze regionali di chiusura dei 'propri confini' (2020) Diritti Fondamentali.it
} 
importance of citizens' well-being according to the principle of leaving no one behind.59 In this sense particular regard should also be recognized to mental health. In fact, many studies have demonstrated how quarantine's period induce mental problems, such as depression, alienation, and uncertainty about the future. ${ }^{60}$

On all these reasons, it is necessary to pursue solutions that take into account both international recommendations and human rights law, in order to secure the right to equality and, more generally, the right to an adequate standard of living for everyone.

\section{PART 5. PROPOSED MEASURES TO REDUCE THE GAP BETWEEN BIG CITIES AND SMALL TOWNS}

During the Covid-19 pandemic, cities appeared deeply different from each other. For this reason, especially during this period of emergency, it is required to adapt the national measures imposed to struggle against the virus to the specific needs of each city area. In this sense, the confinement measures should take into account the disparity among cities that were already present before the emergency. In fact, it has been highlighted how living isolated in a small town is more difficult compared with living in a large city, because of the lack of services and equal opportunities.

To mitigate inequality, an alternative may be to extend the boundaries of small towns, encompassing closer ones, until they meet the same population density as a major urban center. ${ }^{61}$ In the case of Italy, for example, it might be considered to aggregate several small cities until they reach

\footnotetext{
59 UNSDG, 'Universal Values': A major cause of people being left behind is persistent forms of discrimination, including gender discrimination, which leaves individuals, families and whole communities marginalized, and excluded

60 See para II

${ }^{61}$ The fact that the boundaries have only been extended for small towns with fewer than 5,00o residents is insufficient to overcome the gap with the big cities. Indeed, there is more discrimination in this approach since small municipalities with populations little more than 5,000 people cannot access the same services.
} 
the same population density as a major city like Rome, which would provide better opportunities for access to essential services and employment. In this regard, the association between the spread of Covid-19 and population density should be considered. The question then is: is density a risk factor in the growth of the contagion spreads? In this regard, many specific studies have shown that the incidence and mortality of the Covid-19 disease are not directly correlated with the city's density population. ${ }^{62}$ For example, a study published in the Journal of the American Planning Association, examining Covid-19 infection and death rates across 913 metropolitan counties in the US, has shown that county density has little to do with infection. ${ }^{63}$ The same consideration has also pointed out by the UN Secretary, who has argued that it is not just density but underlying economic and social factors in cities that render cities more vulnerable to Covid-19. ${ }^{64}$

These results are important in order to demonstrate how actually important it is to build compact cities model in response to Covid $-19^{65}$. Compact cities are well-designed and integrated areas that reduce inequalities, ensuring adequate standard of living and greater economic efficiency for all people. ${ }^{66}$ Its key characteristic are the major accessibility to local service and employment

\footnotetext{
${ }^{62}$ Aroldo V Ribeiro and others, 'City size and the spreading of COVID-19 in Brazil' (2020) 15(9) PLoS ONE $<$ https://doi.org/10.1371/journal.pone.0239699> accessed 3 May 2021

${ }^{63}$ Luis E C Rocha and others, 'The Non-linear Health Consequences of Living in Larger Cities' (2020) 92(5) Journal of Urban Health < https://doi.org/10.1007/s11524-015-9976-X $>$ accessed 3 May 2021

${ }^{64}$ UN, 'Policy brief COVID-19 in a Urban World' (2020), 23; Luis M A Bettencourt and others, 'Growth, innovation, scaling, and the pace of life in cities' (2007) 104(17) PNAS <https://doi.org/10.1073/pnas.0610172104> accessed 3 May 2021; Luis M A Bettencourt, 'The Origins of

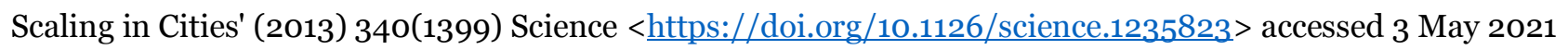
65 Ayyoob Sharifi, Amir Reza Khavarian-Garmsir, The COVID-19 pandemic

${ }^{66}$ Kamni Gill and others, 'Corona, the Compact City and Crises' (2020) 15(1) Journal of Landscape Architecture $<$ https://doi.org/10.1080/18626033.2020.1792647> accessed 3 May 2021; HaeRhan Shin, 'Governing the city through im/mobilities during COVID-19 - technological self-governance' (2020) Eurasian Geography and Economics < https://doi.org/10.1080/15387216.2021.1913206 > accessed 1 May 2021
} 
opportunities, because its density can bring together many citizens needs in the same place. ${ }^{67}$ Therefore, during Covid-19, policy-makers should recognize the non-linear effect of density population when they apply restrictive measures - moreover the containment ones-, extending the boundaries and building more efficient and inclusive cities for the present and especially for the future.

\section{CONCLUSION}

Covid-19 is not only a health issue, but it has also raised questions about many other aspects of people's lives. Since the latter occurs mostly in cities, the aim of this essay has been to examine the relationship between city and the law during the pandemic, especially focusing on the differences between larger cities and small towns. First of all, it has illustrated the main inequalities that occur not only between states, but also between cities within the same national territory. These disparities often concern: the right to access to employment - especially for women - the right to access essential services and, more generally, the right to live with dignity, also safeguarding mental health.

It has been examined through this perspective how governments' restrictive measures to contain the pandemic could violate human rights under international law. States have been shown to have the authority to impose derogations from rights provided they meet the conditions set out in international treaties. Therefore, in this context, the role of UN organizations in promoting the implementation of the most vulnerable areas during the pandemic has been highlighted. According to UN-Habitat documents, it is particularly important to create cities that are resilient and conform to the principle of leave no one behind as well as the SDGs too. Policy makers, in this sense, should

${ }_{67}$ OECD, 'Compact City Policies - A Comparative Assessment' (2012); UN, Policy brief COVID-19 in an Urban World, 8 
pay attention to local areas and small towns vulnerabilities, trying to adapt the measures, adopted to contain the pandemic, to the needs of the zones.

Despite that, currently, many states have not yet adapted to these recommendations, adopting instead measures which have increased the gap between rich and poor, and leaving behind part of the population who live in less developed urban areas. This is what is happening in Italy, for example, where the pandemic has intensified the huge divide between northern and southern cities, especially small towns. In this national background, it has been shown how in small towns in the South, as a result of strict confinement policies and the use of zone colors, many people have lost their jobs or are unable to find employment due to the closing of the main economic activities and the impossibility to leave their residences.

In the final section of the article, it has thus been proposed that a solution to the issue of urban inequality might be to divide the territories into larger and more compact city centers, granting all access to the same services and opportunities. This suggestion is supported by studies that indicate minimal association between population density and the spread of Covid-19, as well as UN recommendations that have seen Covid-19 as an incentive to rebuild cities in a new and more compact way in the future. Supporting this approach means more opportunities for everyone, as well as economic and environmental benefits. 